\title{
Sustainability and Relationality Within Early Childhood Care and Education Settings in Aotearoa New Zealand
}

\author{
Jenny Ritchie
}

Published online: 21 February 2013

(C) Springer Science+Business Media Dordrecht 2013

\begin{abstract}
This paper discusses one aspect of a recently completed two-year study, that of the enactment of relationality within early childhood care and education practice. The research project, Titiro Whakamuri, Hoki Whakamua. We are the future, the present and the past: caring for self, others and the environment in early years' teaching and learning, involved ten early childhood centres from across New Zealand (Ritchie et al. 2010). Relationality refers to our lived relation to other human beings, other living creatures, and to the non-living entities with whom we share our spaces and the planet. The study has demonstrated some ways in which early childhood educators were able to extend children's understandings of their relationality, their connectedness to others, and to the natural world, following theoretical underpinnings of the Indigenous Māori, such as manaakitanga (caring, generosity) and kaitiakitanga (environmental stewardship) (Tikanga Māori. Living by Māori values, Wellington, Huia, 2003), and of western epistemologies such as an ethic of care (The challenge to care in schools: An alternative approach to education, New York, Teachers College Press, 2005a; Educating citizens for global awareness, New York, Teachers College Press, 2005c, Philosophy of education, Boulder, Westview Press, 2007).
\end{abstract}

Keywords Ecological sustainability $\cdot$ Relationality $\cdot$ Indigenous perspectives

Résumé Cet article aborde l'un des aspects d'une étude d'une durée de deux ans, récemment complétée, soit l'application du concept de la dimension relationnelle

\footnotetext{
I greatly appreciate the work and support of my co-directors of this study, Cheryl Rau, Iris Duhn and Janita Craw For reasons of space, this paper focuses on just one of the four research questions explored in the original study (Author and Co-authors, 2010). The full report of the study is available on the TLRI website: http://www.tlri.org.nz/sites/default/files/projects/9260-finalreport.pdf

A glossary is provided for Māori terms. Translations are provided in brackets on first usage.
}

J. Ritchie $(\bowtie)$

Unitec Institute of Technology, Te Whare Wānanga o Wairaka, Auckland, New Zealand

e-mail: jritchie@unitec.ac.nz 
dans la pratique des établissements pour la petite enfance. Le projet de recherche, « Titiro Whakamuri, Hoki Whakamua. Nous sommes le futur, le présent et le passé : prendre soin de soi, des autres et de l'environnement dans le cadre de l'enseignement et de l'apprentissage préscolaire », a impliqué dix centres de la petite enfance à travers la Nouvelle-Zélande (Ritchie et al. 2010). La dimension relationnelle fait référence à nos interactions avec les autres êtres humains, les autres créatures vivantes et les entités non animées avec qui nous partageons l'espace et la planète. L'étude a démontré que les éducateurs de jeunes enfants disposaient de certains moyens pour mieux faire comprendre aux enfants leurs relations et leur connexion avec les autres et avec le monde naturel, selon des concepts théoriques provenant des indigènes maoris, comme le manaakitanga (affection, générosité) et le kaitiakitanga (intendance de l'environnement) (Tikanga Māori. Living by Māori values, Wellington, Huia, 2003), et d'épistémologies occidentales comme une éthique de sollicitude (The challenge to care in schools: An alternative approach to education, New York, Teachers College Press, 2005a; Educating citizens for global awareness, New York, Teachers College Press, 2005c, Philosophy of education, Boulder, Westview Press, 2007).

Resumen Este trabajo analiza uno de los aspectos de un estudio de dos años concluido recientemente, el de la puesta en práctica de la relacionalidad dentro de la educación en la primera infancia. El proyecto de investigación, Titiro Whakamuri, Hoki Whakamua, «Somos el futuro, el presente y el pasado: el cuidado de uno mismo, de los demás y del medio ambiente en la enseñanza y el aprendizaje en la primera infancia », incluyó diez centros educativos de primera infancia alrededor de Nueva Zelanda (Ritchie et al. 2010). La relacionalidad se refiere a nuestra relación vivida con otros seres humanos, otras criaturas vivientes y las entidades no vivientes con quienes compartimos nuestros espacios y el planeta. El estudio ha demostrado algunas maneras en las que los educadores de la primera infancia pudieron ampliar el entendimiento de los niños con su relacionalidad, su conectividad con los demás y con el mundo natural, siguiendo fundamentos teóricos básicos de la población indígena maorí, tales como manaakitanga (cuidado, generosidad) y kaitiakitanga (responsabilidad sobre el cuidado del medio ambiente) (Tikanga Māori. Living by Māori values, Wellington, Huia, 2003), y de epistemologías occidentales como la ética del cuidado (The challenge to care in schools: An alternative approach to education, New York, Teachers College Press, 2005a; Educating citizens for global awareness, New York, Teachers College Press, 2005c, Philosophy of education, Boulder, Westview Press, 2007).

\section{Introduction}

We are living in a time of increasing concern about widespread economic and ecological crisis (Chan et al. 2009; Elliot and Davis 2009). The prevailing neoliberal capitalist economic system prioritises economic drivers over those of social justice and ecological considerations. Western globalisation is perpetuating another era of colonisation of Indigenous peoples, this time through international agencies 
such as the International Monetary Fund and World Bank, along with the policy thrust of organisations such as the Organisation for Economic Co-operation and Development. Our wider education policy contexts, having been 'colonised by economic policy imperatives' (Cope and l'Anson 2003, p. 219) currently reflect this privileging of the economy over the needs of children, families and educators. Early childhood care and education philosophy and pedagogy, in upholding relationality through its intrinsic notions of care and well-being, might be considered to be uncomfortably positioned alongside this economically-driven perspective.

Indigenous peoples have generated their ways of knowing, being and doing, over long periods of time of living in particular ecological contexts, refining their understandings of how to live respectfully and responsively in that place, alongside the plants, birds, insects, fish and animals with whom they share that locale. Living closely in this way means that their knowledges of how to live well in that place have emerged 'from a symbiotic relationship between nature and underlying transformations', adaptations having been made in response to environmental circumstances which have enabled survival over time (Lauderdale 2008, p. 1839). Key to this survival is the emphasis on serving the collective, one's relationality and identity positioning is sited in the context of this group membership:

The Pākehā/Western concepts of individuality and values of autonomy, freedom, self-interest, entitlement, competition, and so on are inconsistent with the concepts of indigenous individuality where individuality is more likely to be constituted on values of relationality, collectivity, reciprocity, and connectivity to prior generations (Raumati Hook 2007, p. 4).

Relationality is central to Māori conceptualisations as expressed in concepts such as mauri (life force), manakitanga (the obligation to be generous and hospitable) and kaitiakitanga (the responsibility to act as guardians of our natural environment) (Mead 2003; Ritchie 1992). According to theologian the Rev. Māori Marsden (2003), mauri is the force that interpenetrates all things to bind and knit them together and as the various elements diversify, mauri acts as the bonding element creating unity and diversity' (p. 60). It is thus the energy 'which impels the cosmic process onwards towards fulfilment' (p. 49) ensuring that the well-being of people 'corresponds with the well-being of the earth' (p. 51). Manaakitanga, is the 'process of showing and receiving care, respect, kindness hospitality' whereby mana (prestige) is generated for both giver and receiver, an embodiment of mutual respect (Benton et al., 2007, p. 186). Kaitiakitanga can be viewed as a socio-environmental ethic of accountabilities, reciprocities and trusteeship involving the relationality of humans, environment, and the spiritual dimension. It 'weaves together ancestral, environmental and social threads of identity, purpose and practice' (Kawharu 2010, p. 227).

An ethic of care, involving caring for others, can be extended to include a responsibility to care for the Earth, according to Noddings (2005b). Noddings further argues that we have a pedagogical responsibility to foster a sense of global citizenship and considers that 'Protecting the Earth is one of the most important tasks facing global citizens' (Noddings 2005b, p. 9). Sustainability refers to 'a method or way of life and human activity indefinitely' (Noddings 2005c, p. 60). 
Fostering in children a sense of belonging, respect for difference, dispositions for peaceful relationships, and knowledge and strategies for ecological sustainability are objectives of education for sustainability in Noddings' view.

The notions of an ethic of care, of mauri, manaakitanga and kaitiakitanga have significant implications for all planetary beings, at this time of increasing concern about our planet's wellbeing, which the United Nations is addressing through its nomination of 2005-2014 as the Decade for Education for Sustainable Development. The United Nations Educational Scientific and Cultural Organisation (UNESCO) recognises that 'We have to learn our way out of current social and environmental problems and learn to live sustainably' (UNESCO 2010, p. 1). The UNESCO framework addresses social, cultural, economic and environmental contexts for 'sustainability'. Living sustainability involves recognising our intersubjectivity as planetary beings (Johansson 2009). This paper will report on how some early childhood care and education centres have been supporting children's awareness and enactment in relation to social and ecological relationality.

\section{Curriculum Documents and Relationality}

Curriculum documents such as Aotearoa New Zealand's Te Whāriki: He whāriki mātauranga mō ngā mokopuna o Aotearoa: Early childhood curriculum (Ministry of Education 1996) and Australia's Being Belonging and Becoming (Commonwealth of Australia 2009) articulate expectations regarding both social and ecological relationality. The kaupapa Māori (Māori philosophy) section of Te Whäriki, exorts teachers to ensure that children know the Sky Father and Earth Mother, their children, and the stories that relate to them (Kia mōhio hoki ki a Ranginui rāua ko Papatūānuku, ā rāua tamariki, me ngā kōrero mō rātou) (Ministry of Education 1996, p. 35). This excerpt from the 'Belonging' strand of Te Whäriki discusses the right of families to a sense of 'belonging', mentioning specifically indigenous families and ecological sensibilities:

The families of all children should feel that they belong and are able to participate in the early childhood education programme and in decision making. Māori and Tagata Pasefika children [Pacific Islands] will be more likely to feel at home if they regularly see Māori and Pacific Islands adults in the early childhood education setting. Liaison with local tangata whenua [indigenous people] and a respect for Papatuanuku [Earth Mother] should be promoted. (Ministry of Education 1996, p. 54)

Inter-human and ecological relationality are similarly juxtaposed in a list of expected "learning outcomes" for the Te Whäriki strand of Exploration, which include:

- A knowledge of features of the land which are of local significance, such as the local river or mountain;

- Theories about social relationships and social concepts, such as friendship, authority, and social rules and understandings; 
- A relationship with the natural environment and a knowledge of their own place in the environment;

- Respect and a developing sense of responsibility for the well-being of both the living and the non-living environment;

- Working theories about the living world and knowledge of how to care for it (Ministry of Education 1996, p. 90).

The more recently promulgated Australian Early Years Learning Framework, Belonging, Being and Becoming (Commonwealth of Australia 2009), also has a central focus on relationality at the heart of its conceptualisation. In this document, 'Belonging acknowledges children's interdependence with others and the basis of relationships in defining identities' (p. 7), 'Children learn to interact in relation to others with care, empathy and respect' (p. 24), and learning environments are described as potentially providing opportunities that 'highlight our responsibilities for a sustainable future and promote children's understanding about their responsibility to care for the environment' (p. 16). Giugni (2011, p. 13) points out, following Deleuze (1993), the 'leakages' trickling between the ideas articulated in such non-prescriptive curriculum documents, and the potentialities and limitations of pedagogical practices. The constructs within these documents cannot be viewed as 'fixed' or 'normative.' Rather, we can recognise that they are fluid and overlapping. These non-prescriptive curriculum documents allow for and encourage subjective, contextually and socio-culturally responsive applications.

\section{Dispositions for Ethical Relationality}

The Western rationalist scientific paradigm which dominates a great many contemporary educational discourses (Cannella 1999), compartmentalises knowledge into boxes and frequently positions the learner as a vessel to be filled by an expert who transmits this pre-determined knowledge (Freire 1972). Early childhood care and education philosophies as expressed through Te Whäriki and Belonging, Being and Becoming, provide an alternative, holistic model, repositioning children, families and the community as central in the co-construction of relational, situated, interactive pedagogies and knowledges. Instead of transmitting facts, educators are encouraged to foster in young children a range of 'dispositions' for learning. Margaret Carr takes the view that 'learning dispositions are about responsive, reciprocal relationships between the individual and the environment' (Carr 2001, p. 22). Children are encouraged to develop these dispositions by experiencing respectful, responsive, reciprocal relationships with people places and things. In the field of early childhood care and education, furthermore, we are ideally positioned to foster dispositions of relationality that involve not only caring for ourselves and others but a sense of guardianship for our environment. This is much more than 'educationally appropriate' practice, or 'good pedagogy'-it is vitally important given the crisis that our planet is facing as a result of the global capitalism's technocratic exploitation of natural resources, and the increasingly apparent drastic impact of global warming on climate change (Riley-Taylor 2002; United Nations 2010). 
Awareness of the centrality of this relationality situates our work as educators as 'profoundly ethical' (Cope and l'Anson 2003, p. 228). This ethical positioning relies on a critically reflexive consciousness about the power of our role as educators in generating programmes that demonstrate and support dispositions and processes of hopeful, life-enhancing relationality (Denzin 2009). Martin Buber considered that 'each human comes equipped with an instinct for communion and that it is up to the educator to both sanction that instinct and provide opportunities for it to flourish' (Buber 1969, as cited in Blenkinsop 2005, p. 287). For Buber, a mystical process of becoming oneself through a conscious search for relationship with the 'other', both people and the 'more-than-human' world (Abram 1996; Plumwood 2006) enables the attainment of a sense of unity, or connection to universal consciousness, which Buber relates to the Jewish construct of 'tikkun' (as cited in Blenkinsop 2005, p. 288). Tikkun olam is the ethical obligation to repair the world (Jacobsen and Steigmann 2010; Robinson 2000).

\section{Methodology and Research Questions}

This project had the overall aim of illuminating philosophies and pedagogical practices within early childhood care and education settings in Aotearoa New Zealand that reflected an ethic of care for self, others, and the environment, as a response to the increasing global awareness in relation to the need for cultural change in support of ecological sustainability. The project had four key research questions:

1. What philosophies and policies guide teachers and whānau (families) in their efforts to integrate issues of ecological sustainability into their current practices?

2. How are Māori ecological principles informing and enhancing a kaupapa (philosophy) of ecological sustainability, as articulated by teachers, tamariki (children) and whānau?

3. In what ways do teachers/whānau articulate and/or work with pedagogies that emphasize the interrelationships between an ethics of care for self, others and the environment in local contexts?

4. How do/can centres work with their local community in the process of producing ecologically sustainable practices?

Findings pertaining to all four of these questions are reported more fully in the final report for the project (Ritchie et al. 2010). This paper extends the theorising of the third research question, taking the notion of relationality as a key finding of the original research, and exploring this further.

The research project was determinedly grounded, as is the curriculum document Te Whäriki, in a paradigm emanating from Te Tiriti o Waitangi/The Treaty of Waitangi. This 1840 agreement between Māori and the British Crown, allowed for colonial settlement of Aotearoa in return for protecting Māori self-determination and rights to their lands and resources including Māori knowledges and values 
(Mutu 2010). Kaupapa Māori (Māori philosophical) constructs were thus foundational in our framing of the study, including awareness of kaupapa Māori research methodologies (Bishop 1996, 1997).

The project employed a qualitative research methodology (Kincheloe 1991) informed by kaupapa Māori approaches, and ethnographic modes (Aubrey et al. 2000). Four co-directors worked alongside the teachers (educator co-researchers) of ten early childhood care and education centres from across Aotearoa New Zealand, supporting these teachers throughout the data-gathering process. Once ethical approval had been received, the co-directors facilitated a one-day introductory hui (meeting), attended by all the teachers, as well as kuia and kaumātua (Māori elders). This meeting was an opportunity to workshop ethical understandings and processes, as well as to discuss and plan a range of methodological strategies. Teachers from five of the early childhood care and education centres had participated in two earlier related studies (Ritchie and Rau 2006, 2008), and were therefore able to share with the teachers who were new to researching, some of the strategies that they had previously found effective. A rich range of data was subsequently gathered over a period of 12 months (2008-2009) through a variety of different methods which included: pedagogical documentation of children's art and narratives; digitally recorded and transcribed interviews by teachers of children and parents; discussions between co-directors and educator co-researchers which were also recorded and transcribed; educators' written narratives; photographs; video of centre activities; and documents such as minutes of whānau hui (centre meetings for parents).

Processes for data analysis and theorising included dialogical negotiation of meaning (Siraj-Blatchford and Siraj-Blatchford 1997) and collaborative storying (Bishop 1996, 1997) through hui (meetings) involving educator co-researchers and the project co-directors. Data gathered from different centres was shared and discussed periodically as co-directors met with clusters of teachers in different regions. Teachers reported that they found this process inspirational and beneficial in terms of the opportunities afforded for expanding their repertoires of both pedagogical and methodological strategies. At the end of the data-gathering phase of the study, a second day-long hui took place, at which each centre reported an overview of their findings from participation in the study, with lively discussion and analysis taking place in response to each presentation. These presentations and discussion were also recorded and transcribed, thus contributing another layer of data and analysis to the overall study.

The following section of this article explores some of the data pertaining to the third research question, focussing on the educators' articulation of their work in relation to the interrelationships between an ethics of care for self, others and the environment within their early childhood care and education centre programmes. This is followed by an illustration of some of the children's understandings regarding relationality, and lastly some examples of ways in which whānau/parents became involved in the early childhood centre programmes. Permission was sought and obtained for centres' and peoples' real names to be reported, and images and photos have also been used with consent. 


\section{Educator Co-researchers' Perspectives}

Educators came to the project with a range of interests which included a strong focus on early childhood care and education for sustainability, and/or a commitment to implementing programmes which reflected te ao Māori (the Māori worldview). During the course of the project, many of the educators reported that their work within the research project had impacted at a variety of levels, in terms of deepening their shared philosophy as a team, and also in the ways that it created a 'ripple effect' from the tamariki (children) and whānau (families) outwards into their communities (Barker 2010; Ellwood 2010; Vaealiki and Mackey 2008).

Teachers from Papamoa kindergarten reported their heightened awareness of a range of Māori concepts pertaining to relationality and sustainability:

The concept of whakawhanaungatanga (relationship-building), a sense of community. Through the young child we have the opportunity to influence change in family and community behaviour by involving, connecting and educating them in an environment...and environmental awareness and sustainable practices. It is so important to create a sense of belonging, a sense of tūrangawaewae [place of belonging], within the kindergarten community, and not working in isolation. The community has a lot to offer that we value being a part of. Whakapapa, Māori genealogy, links us with the whenua, our land, moana, our sea, and cultural concepts working with family and whānau. And our pepeha [statements of identity], the children's genealogy and where that comes from increased our connections, relationships and valuing who people are and where they come from. Children see adults talking and connecting with each other which gives them a sense of mana [esteem] and pride. [Papamoa Kindergarten]

The teachers of Collectively Kids Childcare and Education Centre expressed their sense of relationality with the natural world, recognising that

... nature is not something we can own, we are a part, not above the environment and to have a responsibility to use the resources in a way that doesn't damage the system as a whole ... [Collectively Kids]

For these educator co-researchers, the connection between relationality and sustainability was evident, with these teachers expressing their view that there is a 'natural Māori kaupapa around the sustainability project' within their early childhood care and education programme. They are consciously educating not only about kaitiakitanga (caring for the land) but also about manaakitanga (caring for people).

At Bellmont Kindergarten Te Kupenga in Hamilton, teachers Pat and Pera were very much focussed on implementing their centre philosophy which they describe as operating under the cloak of whanaungatanga (including families) which embraces: Whakapiripiri mai - coming together; Manaakitanga - caring and sharing, making people feel at ease; and Rangimarie-peace. Pera explains their philosophy further: 
Once you've opened up one heart, you'll open up many and the children that come here, the parents, everybody and then you extend out to the grandparents and they feel that they have a special place here. There are mihi [greeting]) too every morning ...that empowers that kuia [female Māori elder] to know that, "Yeah I feel special here, this is my tūrangawaewae [place of belonging] and I'm proud to be here." So they bring more mokopuna [grandchildren]! The word gets out. They keep coming back, coming back. It's that puna [fresh water spring, source] of love. Love, respect, rangimārie [peace]. Everything our philosophy is all about. [Bellmont Kindergarten Te Kupenga]

For some of the teachers in the study the research expectation to include kaupapa Māori perspectives in relation to sustainability had initially seemed a little daunting, something that was new to their programme. Persevering beyond this initial hesitance and with the support of kaumātua (elder) Huata Holmes and a Senior Teacher from the Dunedin Kindergarten Association, Lee Blackie, the educator coresearchers from Richard Hudson Kindergarten grounded their work with tamariki (children) in local Southern Māori creation stories. Towards the end of the study they acknowledged that these Māori perspectives had added a deeper dimension to their work with both tamariki and whānau (children and families):

If we hadn't had the challenge of bringing in a Māori component to the project, it just would never have had the depth, the emotion, the identity and the wholeness that weaving te Ao Māori (the Māori world) has accorded [Richard Hudson Kindergarten]

At Koromiko Kindergarten, in Hawera, the teachers introduced a whakatauki (proverb) to frame their research focus, and explained it as follows:

Manaaki Whenua. Manaaki Tangata. Haere whakamua.

Care for the land. Care for the people. Go forward.

This is the whakatauaki [proverb] that informs and guides our research. With the principles of Education for Sustainability, we want to practice ourselves, and promote the idea for our tamariki and whānau [children and families], about being guardians/caretakers (kaitiaki) of our land and living things. It applies directly to caring for the kindergarten grounds and pets but also to the wider environment... [Koromiko Kindergarten]

Relationality can be seen as central to the enactment of all these co-educators, and became evident in the conceptualisation that tamariki (children) expressed also.

\section{Tamariki (Children's) Enactment of Relationality}

The research kaupapa (philosophical approach) opened up positionings and validation for children's relationality, and in particular affirmation of the ways of being, knowing and doing of tamariki and whānau Māori (Māori children and their extended families). At Richard Hudson Kindergarten, the focus on caring for 
Papatūānuku (Earth Mother) resonated with the tamariki. P-C dictated the following story to explain a painting she had done:

Papatūānuku had too much rubbish on her, because someone had dropped too much rubbish on her. I didn't know who dropped it on her. Rangi (Sky Father) actually saved her, because he threw all the rubbish away in the rubbish bin. It was a really naughty person that dropped the rubbish on Papatūānuku - they didn't have a rubbish bin. The naughty person is in jail now. [P-C, Richard Hudson]



P-C's picture and story, Richard Hudson Kindergarten

In response to activities and discussions at Hawera Kindergarten, K. shared the following narrative regarding his home experiences with his grandparents:

My Nanny B. and T. have a garden... they grow tomatoes and spuds (potatoes)...they take the weeds out so they don't make the spuds die! They also grow mint and silverbeet so we can mash them into our kai [food]. My Koro (Grandad) and my Nanny go to the beach and get kai from there. My Koro dives in the sea and eels under the rocks to find pauas [abalone] ...sometimes kinas [sea urchins] and mussels. Koro takes me fishing but we haven't caught a fish yet! We go to catch eels at night in the rivers, with a long knife - I have catched one! When I have a headache my Nanny and Mum tell me to lay down where it's nice and quiet so it goes away... and it does! [K, Hawera Kindergarten] 


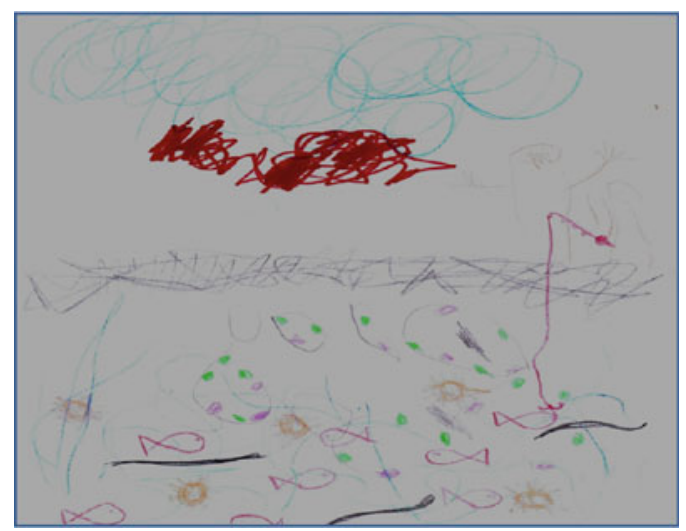

'That's me fishing and that's my Koro (Grandad). I'm catching a fish with my rod, and there's kinas [seaeggs] and pauas [abalone] and eels. My Mum did the fish and I did the rocks. Koro goes in the water and gets them'. [K, Hawera Kindergarten]

Even very young children became fully engaged with activities for sustainability, as seen in the following description from a teacher at Collectively Kids Childcare and Education Centre:

The younger children now compost all their food scraps. We're got a small bin on the kai (food) table and they do this independently. The composting of food scraps has taught the children how much food is being wasted. And one child, while spending time in the over-two area, noticed the large compost bins in the garden and insisted that his parents buy one for them. This was a child who had just turned two years of age, being an advocate for sustainability and having his thoughts and opinions listened to by adults. [Collectively Kids]

The research kaupapa (focus) of relationality in terms of caring for others was evident also in another example from Collectively Kids Childcare and Education centre, again pertaining to under-two-year-olds who were observed to be demonstrating:

Caring for each other, their little acts of kindness, helping, having high expectations of social conscience. One of the children, just over one, for example got a tissue for one of her friends when she was asked by an adult for help. It took her a while to process and act on the request and the piece of tissue she got from the box was tiny, but the event was huge. [Collectively Kids]

At Maungatapu Kindergarten, as part of their approach to the kaupapa of the research project, the educator co-researchers introduced a kindergarten 'treaty' based on Te Tiriti o Waitangi:

Developing a Treaty

We were keen to explore the concepts of manaakitanga [caring] through the kindergarten environment by using the Treaty concepts to share ideas such as: care for self/others and the environment. Through honouring Te Tiriti o 
Waitangi, Article 2, [which] talks about the care for lands, forests and fisheries. As a team, at the beginning of each new term we talk with the children about a contract which allows them to think about what is 'o.k.' and 'not o.k.' behaviour. The children understood the notion of a 'deal' together to keep yourself/others safe, and respecting our environment. Quickly we were able to establish an agreement. Signing the Treaty allowed the children to take ownership to this process and intention of the content, empowering the children to self and peer monitor. We talked with the children about "What is a Treaty?", "Why is it important to have one?" [Maungatapu Kindergarten]

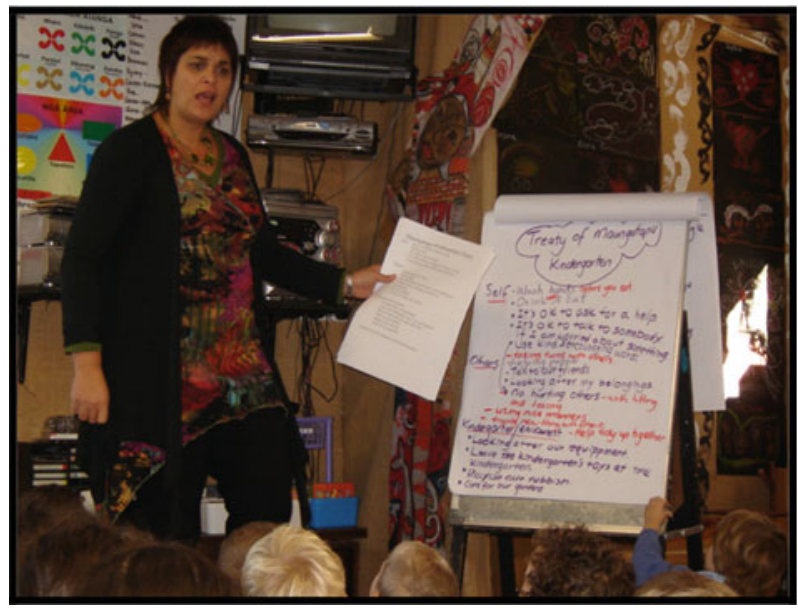

Marion Dekker and tamariki of Maungatapu Kindergarten discuss their kindergarten treaty

Here Marion reports some of the discussion as she and the children negotiated their kindergarten treaty:

What is a Treaty?

R. It's about, so we do not hurt people, it's about sharing.

T. Being nice caring for the kids.

R. We need to look after the animals

$\mathrm{K}$. We look after our toys and the animals, we feed them.

G. So we know all the safe things.

M. It is a deal.

Why do we have one?

I. So that things are fair.

R. So everyone is happy.

R. So that the Māori people are fair. They went to the top of Mauao [a local hill-top], they had songs [part of the Waitangi Day celebration in the city of Tauranga].

K. So we all know what to know.

M. So we all know the rules, so it is fair. [Maungatapu Kindergarten] 


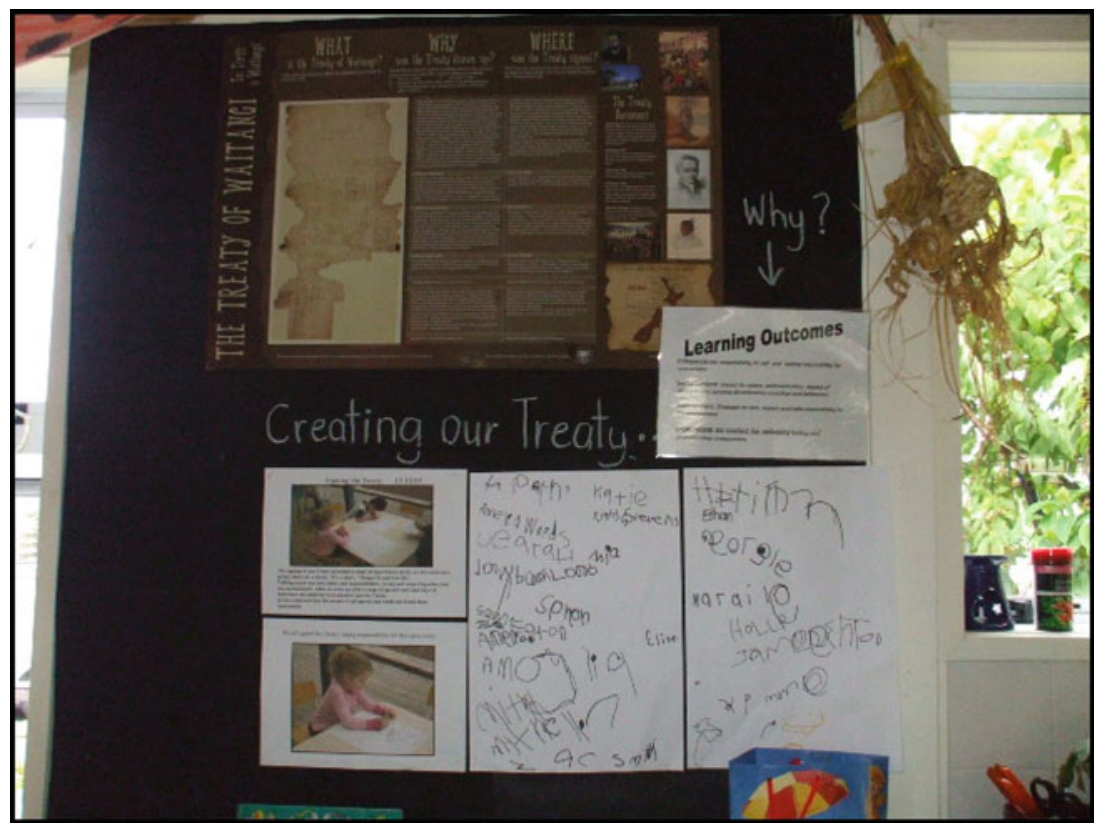

"Creating our Treaty"-Maungatapu Kindergarten

This exercise of negotiating their 'kindergarten treaty' is repeated at the beginning of each term, enabling fresh discussions and re-connection with this kaupapa (focus) of a collective understanding of relationality expectations.

\section{Whānau (Family) Engagement}

Educator co-researchers in this study were sensitive to their role in fostering a shared sense of engagement in the research kaupapa amongst the whannau (families) of tamariki (children) attending their centres. They undertook to inform families of their involvement in the research, and appreciated the richness of experiences that whānau might be able to contribute to their centre's journey, as described here in Koromiko Kindergarten's approach, whereby:

Asking families to contribute their ideas and their knowledge of their children's involvement in environmental issues gave us a more rounded picture of how much knowledge about, and commitment to, Education for Sustainability there is in the wider community. The on-going journey begins to feel like a partnership rather than us forging our way ahead and trying to 'educate' others on what we are doing - some of our families are further ahead on the journey that we are and are providing inspiration for us. [Koromiko Kindergarten]

One family whose child attended Koromiko Kindergarten invited the teachers to visit their home and observe their various and extensive sustainability activities. The 
mother, Debbie, subsequently expressed their appreciation of ways that the research focus had supported them:

What Kindy has taught us:

1) Koromiko has encouraged us to think about how we package food. The trend now continues for school as well as Kindy lunches - we are rarely using non biodegradable packaging.

2) Koromiko philosophies have encouraged us as a family to question how we can continue to be more self-sufficient and environmentally friendly.

3) Koromiko has encouraged us to talk to the children about why we chop wood, plant food, recycle and reduce the things we are putting into bin. [Debbie, Koromiko Kindergarten]

In many centres, a reciprocal cycle of caring was evident as various mechanisms for redistributing excess produce, toys, and clothing were established. These included an ongoing cycle of seedlings and produce being sent to and from children's homes at Raglan Childcare and Education centre, with excess produce being placed in the 'OOOOBY' (Out Of Our Own Back Yards) bowl, to be made into soups and juices; a similar community basket at Bellmont Kindergarten Te Kupenga; and the 'free shelf' for the exchange of used clothing, books and toys at Richard Hudson Kindergarten.

In keeping with their involvement with the Enviro-Schools programme (Enviroschools/Kura Taiao 2009), teachers at Papamoa Kindergarten had established an enviro-group for parents, as Julie Sullivan explained:

We've also developed an 'enviro-group' in our kindergarten which is part of a group that we ask families if they're interested in coming along to meetings that give them information about things that we're doing in the kindergarten and also we work on projects and we also give them information on things maybe that they could be doing at home or things that we need at the kindergarten. We've found it a wonderful group because people have become inspired to help us. They've also become really resourceful because we need maybe to make a water system in the sandpit and so we've got fathers coming along, putting their barrels in and connecting things...this water system. [Julie, Papamoa Kindergarten]

Parents in the various kindergartens offered their direct support to the research kaupapa in many ways, such as providing yoga sessions for tamariki, building and gardening at the centre, and attending centre festivities such as Matariki (a celebration of the Māori New Year, named for the constellation of Pleiades). Pera, teacher at Bellmont Kindergarten Te Kupenga, explained how sharing kai (food) is an important way of demonstrating manaakitanga:

I think it's just about empowering people. Giving them a voice. Giving them [a sense of being] part of our whānau [centre 'family']. Making them feel special and included and that's what F. said, "Oh why don't we have a hāngi [Māori feast, cooked in an earth oven]?” I said "Right, let's get cracking!" So 
away we went. You know we had M., one of our students here, he's from the Solomon Islands. Oh well, I can get him to make coconut bread and cassava rolls. And then M. from the Congo. You know we're going to have 'fufu'. And then we have all our Indian whānau [families] as well - butter chicken, naan bread...

This sharing of kai from diverse whānau members is a demonstrable enactment of relationality, of the centre community members respecting and caring for each other. As Sharon Todd has written, 'Community and responsibility would then seem to arise at the moment difference ceases to be an impediment for understanding' (Todd 2004, p. 338).

\section{Overview of Findings}

In the examples from the data presented above, it is possible to observe the teachers' conscious articulation of their intent to offer pedagogies which foster children's understandings of relationality. In many cases, educators employed conceptualisations from te ao Māori (the Māori world) which are inherently relational, such as whakawhanaungatanga (relationship-building), generating a sense of community within the early childhood care and education centres, and of kaitiakitanga, (caring for the environment). The teachers valued the depth that these Māori constructs brought to their programmes and noticed also the way in which these notions, such as caring for Papatūānuku, our 'Earth Mother,' had great resonance for the children, as demonstrated in their art and stories.

Along with the intentional generation of collectively held notions of relationality such as caring and responsibility for others and for the environment, as illustrated in the 'Kindergarten Treaty' devised with three and four year-olds at Maungatapu kindergarten. Teachers also observed even very young children demonstrating caring for each other as well as for the environment, as described by teachers from Collectively Kids Childcare and Education Centre .

The data also provides us with examples of the reciprocal involvement of parents/whānau in the programme offered by the early childhood care and education centre, some of whom already had a strong focus within their homes on sustainability practices and/or kaupapa Māori values, whilst for others a new interest was stirred in response to that of their child. Families were able to avail themselves of the benefits sharing of surplus garden produce, as well as used clothing, toys and books, and to take part in the collective sharing and hospitality (manaakitanga) of diverse community foods at centre celebrations such as the festivities for Matariki, the Māori New Year. In this way, the early childhood care and education centre became a focus of community-level caring.

In some centres, parents demonstrated their active involvement in the centre's environmental consciousness, such as in the case of the Papamoa Kindergarten enviro-group for parents, who met regularly as a group dedicated towards working to support the kindergarten's environmental projects such as a recycled rain-water system for use by children in the sandpit. This involvement by parents indicates 
their resonance with the issues of environmental sustainability, and their willingness to be proactive in supporting their children's education in these matters.

\section{Discussion}

The New Zealand and Australian early childhood curriculum documents, Te Whāriki (Ministry of Education 1996) and Belonging, Being and Becoming (Australian Government Department of Education Employment and Workplace Relations, 2009) posit curiosity, creativity, imagination, confidence, commitment, enthusiasm, reasoning, investigation, persistence, reflexivity, cooperation and collaboration as desirable dispositions to be fostered through early childhood care and education programmes. This dispositional view reflects a socio-culturally grounded view that is validating of children's and families cultural values and priorities, whereby children are encouraged to collaborate alongside adults in the culturally valued activities of their community, and through this gain knowledge and skills that they can apply later in their lives (Rogoff 1995). Children in this view are reliant on adults to provide this guidance and stimulation. In fact, the role of educators can be viewed as being to thoughtfully stimulate and generate dispositions of the children in their care, as opposed to a reactive model of purely responding to the interests demonstrated by children.

As evidence of the 'climate crisis' becomes increasingly apparent, it becomes urgent that educators consider our ethical response to the challenges that future generations will face with regard to issues of sustainability (Johansson 2009). The argument of this paper is that as educators we have the responsibility to offer the tamariki (children) in our care opportunities to develop dispositions of relationality to both human and 'more-than-human' entities with whom we share our places and spaces. These dispositions, such as empathy, kindness, cooperation and respect are expressed in Māori understandings such as manaakitanga and kaitiakitanga. They include both a commitment to and the enactment of caring for self, others, and the natural world. The aspiration of this ethical responsibility of fostering dispositions of relationality is therefore to equip children with understandings of and commitment to sustainability, as well as peaceful, creative, collaborative strategies with which to face the looming challenges of climate change, water shortage, resource depletion, wilderness destruction, species extinction and increasing competition amongst humanity for access to that which remains.

The examples provided earlier in this article illustrate some ways in which, as teachers introduced Māori conceptualisations relating to kaitiakitanga (guardianship) into the programme, children began to demonstrate empathy with the Earth Mother and Sky Father, extending their expression of an ethic of care, and demonstrating dispositions of relationality beyond their immediate concerns to a wider conceptualisation expressive of our inter-connectedness and interdependence as planetary beings. The worldviews of the Indigenous Māori were validated for their values of respect for the environment. Not only the children, but their families and the wider early childhood communities became involved in reciprocal ongoing cycles of sharing and recycling. That this project generated such responsiveness is 
indicative of the great potential of early childhood care and education services in playing a foundational and leading role in response to the complex multiple challenges of climate crisis, resource depletion, and species extinction as well as the increasing suffering of so many families facing deepening "economic despair" (Giardina and Hess 2007, p. 181). This project has demonstrated the power of early childhood care and education services to foster pedagogies grounded in Indigenous and Western ethics of care, as a means of equipping young children with dispositions of hopeful relationality. It has also foregrounded that educators who focus on delivering early childhood care and education pedagogies committed to environmental sustainability should consider relationality to be a key disposition to be fostered, and that this notion of relationality embraces social and cultural sustainability, as well as environmental sustainability.

Tāku hei piripiri, tāku hei mokimoki, tāku hei tāwhiri, tāku kati taramea.

An endearment sung to young children emphasising the high value placed on looking after children and ensuring that they are loved and nurtured. (Mead and Mead 2010, p. 40)

\section{Glossary of Māori Terms}

$\begin{array}{ll}\text { Aotearoa } & \text { A Māori name for New Zealand } \\ \text { Hāngi } & \text { Māori feast, cooked in an earth oven } \\ \text { Hui } & \text { Meeting; gathering of people } \\ \text { Kai } & \text { Food } \\ \text { Kaitaiki } & \text { Guardians, caretakers } \\ \text { Kaitiakitanga } & \text { Environmental stewardship, guardianship } \\ \text { Kaumātua } & \text { Māori elders } \\ \text { Kaupapa Māori } & \text { Māori philosophy } \\ \text { Kina } & \text { Sea urchin } \\ \text { Kuia } & \text { Female elder } \\ \text { Mana } & \text { Prestige; esteem } \\ \text { Manaakitanga } & \text { Caring and sharing; making people feel at ease; } \\ & \text { generosity; hospitality; the obligation to be generous } \\ \text { Mauri } & \text { and hospitable } \\ \text { Mihi } & \text { Life force } \\ \text { Moana } & \text { Greetings } \\ \text { Mokopuna } & \text { Sea } \\ \text { Pākehā } & \text { Grandchildren } \\ \text { Papatūānuku } & \text { New Zealanders of European descent } \\ \text { Paua } & \text { Earth Mother } \\ \text { Pepeha } & \text { Abalone } \\ \text { Puna } & \text { Statements of identity } \\ \text { Rangi/Ranginui } & \text { Fresh water spring; source } \\ \text { Rangimarie } & \text { Sky Father } \\ \text { Tamariki } & \text { Peace } \\ & \text { Children } \\ & \end{array}$


Tangata whenua

Te ao Māori

Tūrangawaewae

Whakapapa

Whakapiripiri mai

Whakatauki

Whakawhanaungatanga

Whānau

Whanaungatanga

Whenua
Indigenous people; literally 'people of the land'

The Māori worldview

Place of belonging

Genealogy, ancestry

Gather together

Proverb

Relationship-building

Families

Relationships; relatedness

Land

\section{References}

Abram, D. (1996). The spell of the Sensuous. Perception and Language in a More-Than-Human World. New York: Vintage Books.

Aubrey, C., David, T., Godfrey, R., \& Thompson, L. (2000). Early Childhood Educational Research. Issues in Methodology and Ethics. London, New York: Routledge/Falmer Press.

Australian Government Department of Education Employment and Workplace Relations. (2009). Belonging, being and becoming. The early years learning framework for Australia. Barton ACT: Commonwealth of Australia. Retrieved from http://www.deewr.gov.au/Earlychildhood/Policy_ Agenda/Quality/Documents/Final\%20EYLF\%20Framework\%20Report\%20-\%20WEB.pdf

Barker, G. (2010). Building sustainable communities. 'Manaaki whenua. Manaaki tangata. Haera whakamua'. Early Education, 47(Autumn/Winter), 15-18.

Bishop, R. (1996). Collaborative Research Stories: Whakawhanaungatanga. Palmerston North: Dunmore.

Bishop, R. (1997). Interviewing as collaborative storying. Education Research and Perspectives, 24(1), 28-47.

Blenkinsop, S. (2005). Martin Buber: Educating for relationship. Ethics, Place and Environment, 8(3), 285-307.

Cannella, G. (1999). The scientific discourse of education: Predetermining the lives of others-Foucault, education, and children. Contemporary Issues in Early Childhood, 1(1), 36-44.

Carr, M. (2001). Assessment in Early Childhood Settings. Learning Stories. London: Sage.

Chan, B., Choy, G., \& Lee, A. (2009). Harmony as the basis for education for sustainable development: A case example of Yew Chung International Schools. International Journal of Early Childhood, 41(2), 35-48.

Commonwealth of Australia. (2009). Belonging, being and becoming. The early years learning framework for Australia. Barton ACT: Commonwealth of Australia. Retrieved from http://www. deewr.gov.au/Earlychildhood/Policy_Agenda/Quality/Documents/Final\%20EYLF\%20Framework $\%$ 20Report\%20-\%20WEB.pdf

Cope, P., \& l'Anson, J. (2003). Forms of exchange: Education, economics and the neglect of social contingency. British Journal of Educational Studies, 51(3), 219-232.

Denzin, N. K. (2009). Critical pedagogy and democratic life or a radical democratic pedagogy. Cultural Studies $\leftrightarrow$ Critical Methodologies, 9(3), 379-397.

Elliot, S., \& Davis, J. (2009). Exploring the resistance: An Australian perspective on educating for sustainability in early childhood. International Journal of Early Childhood, 41(2), 65-77.

Ellwood, A. (2010). Caring for Papatuanuku. Yesterday, today and tomorrow. Early Education, 47(Autumn/Winter), 19-22.

Enviroschools/Kura Taiao. (2009). Tā tātou kaupapa. About Enviroschools. Retrieved from http://www. enviroschools.org.nz/about-enviroschools

Freire, P. (1972). Pedagogy of the Oppressed. London: Penguin. 
Giardina, M. D., \& Hess, L. A. (2007). If not us, then who? Performing pedagogies of hope in postKatrina America. Cultural Studies $\leftrightarrow$ Critical Methodologies, 7(2), 169-187.

Giugni, M. (2011). 'Becoming worldly with': an encounter with the Early Years Learning Framework. Contemporary Issues in Early Childhood, 12(1), 11-27.

Jacobsen, R., \& Steigmann, M. (2010). A Jewish perspective on peace education. In E. J. Brantmeier, J. Lin, \& J. P. Miller (Eds.), Spirituality, Religion and Peace Education (pp. 37-61). Charlotte: Information Age Publishing.

Johansson, E. (2009). The preschool child of today-the world citizen of tomorrow? International Journal of Early Childhood, 41(2), 79-95.

Kawharu, M. (2010). Environment as a marae locale. In R. Selby, P. Moore, \& M. Mulholland (Eds.), Māori and the Environment: Kaitiaki (pp. 221-237). Wellington: Huia.

Kincheloe, J. L. (1991). Teachers as Researchers: Qualitative Inquiry as a Path to Empowerment. London: Falmer.

Lauderdale, P. (2008). Indigenous peoples in the face of globalization. American Behavioral Scientist, 51(12), 1836-1843.

Marsden, M. (2003). The Woven Universe. Selected writings of Rev. Māori Marsden. T. A.C. Royal (Ed.). Wellington: The Estate of Māori Marsden.

Mead, H. M. (2003). Tikanga Māori. Living by Māori Values. Wellington: Huia.

Mead, H. M., \& Mead, J. (2010). People of the Land. Images and Māori Proverbs of Aotearoa New Zealand. Wellington: Huia.

Ministry of Education. (1996). Te Whāriki. He whāriki mātauranga mō ngā mokopuna o Aotearoa: Early childhood curriculum. Wellington: Learning Media.

Mutu, M. (2010). Constitutional intentions: The Treaty of Waitangi texts. In M. Mulholland \& V. Tawhai (Eds.), Weeping Waters. The Treaty of Waitangi and constitutional change (pp. 13-40). Wellington: Huia.

Noddings, N. (2005a). The Challenge to Care in Schools: An Alternative Approach to Education (2nd ed.). New York: Teachers College Press.

Noddings, N. (2005b). Global citizenship: Promises and problems. In N. Noddings (Ed.), Educating Citizens for Global Awareness (pp. 1-21). New York: Teachers College Press.

Noddings, N. (2005c). Place-based education to preserve the Earth and its people. In N. Noddings (Ed.), Educating Citizens for Global Awareness (pp. 57-68). New York: Teachers College Press.

Noddings, N. (2007). Philosophy of Education (2nd ed.). Boulder: Westview Press.

Plumwood, V. (2006). The concept of a cultural landscape. Nature, culture and agency in the land. Ethics and the environment, 11(2), 115-150.

Raumati Hook, G. (2007). A future for Māori education. Part II. The reintegration of culture and education. MAI Review, 1, 1-17, Retrieved from http://www.review.mai.ac.nz

Riley-Taylor, E. (2002). Ecology, Spirituality, \& Education: Curriculum for Relational Knowing. New York: Peter Lang.

Ritchie, J. E. (1992). Becoming Bicultural. Wellington: Huia Publications.

Ritchie, J., Duhn, I., Craw, J. \& Rau, C. (2010). Titiro Whakamuri, Hoki Whakamua. We are the future, the present and the past: caring for self, others and the environment in early years' teaching and learning. Final Report for the Teaching and Learning Research Initiative. Wellington: Teaching and Learning Research Initiative/New Zealand Centre for Educational Research. Retrieved from http://www.tlri.org.nz/sites/default/files/a-project-pdfs/9260-Author/9260-finalreport.pdf

Ritchie, J. \& Rau, C. (2006). Whakawhanaungatanga. Partnerships in bicultural development in early childhood education. Final Report to the Teaching \& Learning Research Initiative Project. Wellington: Teaching Learning Research Institute/New Zealand Centre for Educational Research. Retrieved from http://www.tlri.org.nz/pdfs/9207_finalreport.pdf

Ritchie, J. \& Rau, C. (2008). Te Puawaitanga-partnerships with tamariki and whānau in bicultural early childhood care and education. Final Report to the Teaching Learning Research Initiative. Wellington: Teaching Learning Research Institute/New Zealand Centre for Educational Research. Retrieved from http://www.tlri.org.nz/pdfs/9238_finalreport.pdf

Robinson, G. (2000). Essential Judaism. A complete Guide to Beliefs, Customs, and Rituals. New York: Pocket Books.

Rogoff, B. (1995). Observing sociocultural activity on three planes: participatory appropriation, guided participation, and apprenticeship. In J. Wertsch, P. Del Rio, \& A. Alvarez (Eds.), Sociocultural Studies of the Mind (pp. 139-164). New York: Cambridge University Press. 
Siraj-Blatchford, I., \& Siraj-Blatchford, J. (1997). Reflexivity, social justice and educational research. Cambridge Journal of Education, 27(2), 235-248.

Smith, L. T. (2005). On Tricky Ground: Researching the Native in the Age of Uncertainty. In N. K. Denzin \& Y. S. Lincoln (Eds.), The Sage Handbook of Qualitative Research (3rd ed., pp. 85-107). Thousand Oaks: Sage.

Todd, S. (2004). Teaching with ignorance: Questions of social justice, empathy, and responsible community. Interchange, 35(3), 337-352.

United Nations. (2010). United Nations Framework Convention on Climate Change. New York: United Nations. Retrieved from http://unfccc.int/essential_background/feeling_the_heat/items/2913.php

United Nations Educational Scientific and Cultural Organisation (UNESCO). (2010). Education for sustainable development (ESD): UNESCO. Retrieved from http://www.environment.gov.au/ education/decade/

Vaealiki, S., \& Mackey, G. (2008). Ripples of action: Strengthening environmental competency in an early childhood centre. Early Childhood Folio, 12, 7-11. 